\title{
FENOMENA GERAKAN SEMPALAN ISLAM DI INDONESIA
}

\author{
Wahyu Iryana \\ Fakultas Adab dan Humaniora UIN SGD Bandung \\ Jalan A.H. Nasution No. 105 Bandung \\ wahyu_iryana@yahoo.com
}

\begin{abstract}
Phenomenon of Islamic Space Movement in Indonesia. The phenomenon of a deviant sect or a splinter movement in among Indonesian muslims recently become very popular in a row of action and its accompanying notes. Many reported the existence of a deviant sect that teaches the doctrine that deviate from the mainstream, or a sect and religion that being its parent. Which appears on the surface, mostly born from Islam as the flow of its parent, such as Salat bilingually in Malang, Ahmadiyah sect and a person who claimed to have had the last prophet or holy book itself like in Brebes, Tangerang, Tulungagung, etc. In Indonesia a negative impression of a splinter group became stronger after the tendency of his movement became a threat to the stability and security of the nation and state. The latest fact about this stigma as seen from the Syi'a and Ahmadiyya group in Kuningan regency, West Java which leads to anarchic behavior. Inevitably the government felt the need to restrict the splinter movements to realize the security in the nation. This jurnal seeks to make a typology of splinter groups that exist among Muslims in Indonesia and explore the factors that led to the emergence of those movements with its various concentric circumference.
\end{abstract}

Keywords: Movement, Muslims, Indonesian

Abstrak: Fenomena Gerakan Sempalan Islam di Indonesia. Fenomena sekte menyimpang atau gerakan sempalan di kalangan umat Islam Indonesia akhir-akhir ini menjadi sangat populer dalam deretan aksi dan catatan-catatan yang menyertainya. Banyak yang melaporkan adanya sekte menyimpang yang mengajarkan doktrin yang menyimpang dari arus utama, atau sekte dan agama yang menjadi induknya. Yang muncul di permukaan, kebanyakan lahir dari Islam sebagai aliran orang tua, seperti Salat bilingually di Malang, sekte Ahmadiyah dan seseorang yang mengaku telah memiliki nabi terakhir atau kitab suci itu sendiri seperti di Brebes, Tangerang, Tulungagung, dll . Di Indonesia kesan negatif dari kelompok sempalan menjadi lebih kuat setelah kecenderungan gerakannya menjadi ancaman bagi stabilitas dan keamanan bangsa dan negara. Fakta terbaru tentang stigma ini dilihat dari kelompok Syi'ah dan Ahmadiyah di Kabupaten Kuningan, Jawa Barat yang mengarah pada perilaku anarkis. Mau tidak mau pemerintah merasa perlu membatasi gerakan serpihan untuk mewujudkan keamanan di negara. Jurnal ini berusaha membuat tipologi kelompokkelompok sempalan yang ada di kalangan umat Islam di Indonesia dan mengeksplorasi faktor-faktor yang menyebabkan munculnya gerakan-gerakan itu dengan berbagai lingkaran konsentrisnya.

Kata Kunci: Gerakan, Muslim, Indonesia.

\section{Pendahuluan}

Dipercaya atau tidak dari hari ke hari, ancaman terhadap kebebasan beragama di Indonesia amatlah serius. Hal ini karena ancaman yang dimaksud terjadi di berbagai ranah, dilakukan oleh pihak yang beragam, dan terus terjadi dalam pola-pola yang sama. ${ }^{1}$ Setiap kekerasan yang terjadi akan selalu ada media yang meliput, karena isu ini memang seksi bagi insan pers kita. Dalam arena publik berbagai isu maupun permasalahan sosial, seperti kekerasan contohnya, selalu menjadi konsumsi publik yang disajikan dengan berbagai perspektif oleh mediamedia yang meliput. Berita terakhir adanya bom di Sarinah, Jalan Thamrin Jakarta merupakan berita terbaru yang masih marak diberitakan. Namun satu hal yang harus di ingat bahwa kita, bangsa 
Indonesia tidak takut dari ancamanan teror apapun, masing-masing dari warga negara Indonesia apapun agama dan sukunya akan selalu menjunjung tinggi semangat kesatuan dalam keragaman.

Pertentangan dalam suatu komunitas akan senantiasa ada dan menggejala ditengah-tengah entitas anggotanya. Tentunya hal itu terjadi bukan tanpa alasan, seperti perbenturan dua muatan positif yang tidak jelas asalusulnya, melainkan ada faktor $x$ yang mempengaruhi perpecahan tersebut, entah itu dari dorongan dalam (faktor internal) maupun dorongan dalam (faktor eksternal).

Begitu juga suatu agama yang terdiri dari berbagai macam umat manusia dengan segala asal-usul, pemikiran, dan motif akidahnya. Pastinya kita akan menemukan indikasi-indikasi perpecahan dan pertentangan diantara penganutnya. Pertentangan tersebut ada yang bersifat radikal maupun sedikit toleran. Lalu timbul pertanyaan kenapa sekumpulan manusia yang terikat kekuatan akidah dan agama bisa mengalami suatu pertentangan, padahal mereka memiliki kesadaran dan ideology yang sama yaitu agama. Pertanyaan selanjutnya begaimana nasib golongan minoritas yang menjadi penantang golongan konservatif sebagai pewaris tradisi lama.

Kemudian begitu banyak peristiwa konfrontasi antar sekte agama-terutama Islam- di Indonesia. Misalnya gerakan Ahmadiyah yang menganggap Mirza Ghulam Ahmad sebagai nabi hingga akhirnya memicu kerusuhan masa diberbagai daerah, seperti perusakan Masjid Ahmadiyah di Kuningan. Contoh lain pengakuan Lia Aminudin sebagai al-
Masih dan malaikat Jibril yang meresahkan masyarakat Indonesia. Kasuskasus diatas hendaklah diperhatikan dan disikapi dengan bijaksana.

Salah satu penyikapan tersebut yaitu dengan menyadari motif yang menyebabkan mereka memutuskan membentuk ajaran menyimpang.Selain itu perlu juga dipahami bahwa vonis "menyimpang" sangat subjektif. Orang tidak bisa menilai suatu hal tanpa kesadaran dan kepentingannya.Dengan demikian kita mesti mempelajari hakikat penyimpangan dan sempalan terutama dalam sudut pandang Islam Indonesia. Hingga pada akhirnya kita bisa lebih arif menyikapi perbedaan keyakinan dan pandangan religius-ideologis.

\section{Metodologi Penelitian}

Dalam metode penelitian dibahas metode yang merupakan pendekatan praktis dalam setiap penelitian ilmiah. Hal ini dimaksudkan untuk memudahkan bagi setiap peneliti mengetahui suatu peristiwa atau keadaan yang diinginkan. Untuk menerapkan teori terhadap permasalahan, diperlukan metode khusus yang dianggap relevan dan dapat membantu memecahkan permasalahan.

Desain penelitian bersifat deskriptif dengan menggunakan metode Historis. Dengan penggambaran dan perincian terhadap penelitian diharapkan dapat mengungkapkan secara jelas data-data yang mendukung tentang bagaimana peran media dalam situasi konflik. Metode Historis deskriptif dapat diartikan sebagai prosedur pemecahan masalah yang diteliti dengan menggambarkan atau melukiskan keadaan objek penelitian berdasarkan fakta-fakta objektivitas yang tampak atau sebagaimana adanya (das 
Sein). Dalam usaha mendeskripsikan fakta itu pada tahap pertama tertuju pada usaha mengemukakan gejala-gejala secara lengkap di dalam aspek yang diteliti agar jelas keadaannya atau kondisinya (factfinding). Sehingga dapat diketahui apakah media berperan sebagai konstruksi atas realita atau sarana pencegah konflik dengan tahapan heuristik, kritik, interpretasi dan historiografi.

Desain penelitian yang bersifat deskriptif dapat diartikan sebagai prosedur pemecahan masalah yang diselidiki dengan menggambarkan atau melukiskan keadaan subjek atau objek penelitian (seorang, komunitas, lembaga masyarakat dll) pada saat sekarang berdasarkan fakta-fakta yang tampak atau sebagaimana adanya. ${ }^{2}$ Fakta-fakta yang didapatkan di lapangan diharapkan dapat memberi gambaran tentang peran media dalam memberitakan sebuah konflik.

Penulis melakukan proses studi pustaka dengan mengunjungi berbagai perpustakaan (library research) dan mengumpulkan data-data primer melalui bahan-bahan tulisan dalam berbagai bentuk, yang diperoleh dari buku, jurnal, koran, majalah, internet dan lain-lain. Dari data-data yang terkumpul, baik melalui proses studi pustaka, diharapkan dapat memudahkan penulis dalam melakukan penelitian ini. Langkah terakhir adalah penulisan (historiografi) dengan tujuan rekonstruksi peristiwa.

\section{Pembahasan Gerakan Sempalan}

Secara etimologi penulis tidak menemukan definisi yang jelas dari arti sempalan dalam bentuk nyatanya. Tetapi Menyempal sebagai kata kerjanya memiliki arti menyembul atau tersembul keluar sebagian, seperti jantung pisang yang baru akan keluar. Kata tersebut juga bersinonim dengan kata menyumpal yang berarti menutup dengan cara menjejalkan sesuatu. Seperti suatu uangkapan "saya terpaksa menyumpal mulutnya agar tidak berteriak-teriak lagi.Itu semua penulis dapatkan dari kamus besar bahasa Indonesia.

Sepertinya definisi yang paling relevan untuk dipakai dalam pembahasan ini adalah pengertian yang pertama. Perilaku aktivis gerakan sempalan yang cenderung memisahkan diri dari induk organisasinya diibaratkan air minum yang tumpah keluar memisahkan diri dari mayoritas anggotanya.Seolah-olah menyembul dengan konotasi bergerak atas kemauan, tanpa ada intervensi asing atau tersembul seakan didorong dari dalam organisasinya.

Ali Rokhmad, dalam tulisannya Aliran Sesat dan Hegemoni Ortodoksi berpendapat menurut terminologis aliran sempalan istilah ini konon pertama kali dipakai oleh Abdurrahman Wahid sebagai pengganti kata "splinter group", kata yang tidak mempunyai konotasi khusus aliran agama, tetapi dipakai untuk kelompok kecil yang memisahkan diri (menyempal) dari partai atau organisasi sosial dan politik. Untuk "splinter group" yang merupakan aliran agama, kata "sekte" lazim dipakai.

Kata sekte, menurut Kamus Besar Bahasa Indonesia (KBBI) merupakan kelompok orang yg mempunyai kepercayaan atau pandangan agama yg sama, yg berbeda dari pandangan agama yg lebih lazim diterima oleh para penganut agama. Ini memiliki persamaan dengan kata madzhab yang diambil dari bahasa Arab yang berarti pendapat atau 
teori. ${ }^{3}$ Artinya sekte bisa dikatakan suatu kumpulan manusia yang memisahkan diri dikarenakan perbedaan sikap dan pandangan tertentu dan diyakini sepenuhnya oleh para penganutnya. Meskipun begitu pemisahan diri ini tidak mengundang konflik berkepanjangan karena kelompok yang ditinggalkannya tidak merasa marah atau terganggu.Inilah salah satu perbedaan sekte dengan makna sempalan ataupun aliran sesat. Bagaimanapun juga penulis luar-terutama Barat- mengasumsikan gerakan sempalan sebagai suatu sekte. Hal ini bisa dilihat dari judul artikel Martin van Bruinessen Sectarian movements in Indonesian Islam: Social and cultural background. kekacauan makna diatas tidak perlu sampai mengalihkan perhatian suatu bahasan. Kita ikuti saja apa yang sudah popular digunakan para penulis dan peneliti gerakan sempalan di Indonesia.

Kemudian pengertian gerakan sempalan bisa dipecah menjadi dua teori yang saling bertentangan.Pertama, gerakan sempalan yang bersifat aliran sesat.Artinya gerakan ini dalam perjalanan organisasinya mendapat tantangan dan reaksi keras terutama dari induk perkumpulannya, atau kalau boleh dikatakan kaum konservatif.Keluarnya mereka merupakan suatu penghinaan dan merendahkan kemurnian keyakinan, ideologi, dan prinsip yang selama ini dianut kaum konservatif.Aktivis konservatif kemudian mencap mereka sebagai kaum pembangkang (ahlul bughot) serta berhak memberikan sikap atas tindakan mereka.Sikap tersebut bisa lunak seperti usaha menyadarkan dan mengingatkannya, ataupun memakai tindak kekerasan seperti pembakaran rumah ibadah Ahmadiyah di Kuningan.

Kedua, gerakan sempalan yang bersifat sekte, sektarian, atau madzhab. Gerakan ini cenderung tidak mengobarkan reaksi keras dari pihak lain. Hal itu disebabkan kaum konservatif menerima perbedaan diantara mereka bahkan dianggap sebagai rahmatan lil'alamin.Misalnya perbedaan pandangan hukum diantara pengikut ahlusunnah wal jama'ah.sejak lahirnya empat madzhab fiqih di dunia Islam ${ }^{4}$ sampai sekarang tampak sedikit pertentanganpertentangan yang disebabkan perbedaan tersebut, karena mereka memang lebih saling toleransi. Berbeda perihal akidah islam, biasanya umat islam sangat reaktif apabila hal tersebut dipertentangkan.

Jadi, sebelum menginjak pembahasan selanjutnya diharapkan kita bisa membedakan mana perbedaan pendapat yang dapat ditoleransi dan sesuai kesepakatan kita beri istilah sekte dan perbedaan pendapat yang tidak dapat ditoleransi atau kita istilahkan sebagai aliran sesat.Dengan demikian kita bisa memisahkan tipologi gerakan yang berkembang ditengah-tengah masyarakat dengan memakai karakteristik di atas.

\section{Pembahasan}
a. Penyebab Munculnya Gerakan Sempalan

Menurut Nunu Burhanudin dalam Annual Conference on Islamic Studies $X$, . Ada beberapa sebab yang melatarbelakangi lahirnya berbagai gerakan sempalan, sebagai berikut. Pertama, Peran ortodoksi yang tidak akomodatif.Secara sosiologi, "ortodoksi" dan "sempalan" bukan konsep yang 
mutlak dan abadi, namun relatif dan dinamis. Sebagaimana diketahui, sepanjang sejarah Islam telah terjadi berbagai pergeseran dalam faham dominan yang tidak lepas dari situasi politik. Dalam banyak hal, ortodoksi adalah faham yang didukung oleh penguasa, sedangkan faham yang tidak disetujui dicap sesat; dan demikian gerakan sempalan seringkali merupakan penolakan faham dominan dan sekaligus merupakan protes sosial atau politik. ${ }^{5}$

Sebagai contoh, faham aqidah Asy'ari, yang sekarang merupakan ortodoksi, pada masa 'Abbasiyah pernah dianggap sesat, ketika ulama Mu'tazilah (yang waktu itu didukung oleh penguasa) merupakan golongan yang dominan.Jadi, faham yang sekarang dipandang sebagai ortodoksi juga pernah merupakan sejenis "gerakan sempalan".Bahwa akhirnya faham Asy'ari-lah yang menang, juga tidak lepas dari faktor politik.Kasus ini mungkin bukan contoh yang terbaik -golongan Asy'ari tidak dengan sengaja memisahkan diri dari sebuah "mainstream" yang sudah mapan; faham yang mereka anut berkembang dalam dialog terus-menerus dengan para lawannya.Contoh yang lebih tepat adalah gerakan Islam reformis Indonesia pada awal abad ini (seperti Al Irsyad dan Muhammadiyah) yang dengan tegas menentang "ortodoksi" tradisional yang dianut mayoritas ulama, dan dari sudut itu merupakan gerakan sempalan.

Kedua, Dalam beberapa kasus terkait gerakan sempalan, latar belakang pendidikan dan pengetahuan agama para anggotanya relatif rendah dan bahkan sama sekali tidak mengerti dasar-dasar agama yang dianutnya, tetapi demikian kebutaan terhadap dasar-dasar agama ini diimbangi semangat keagamaan yang tinggi. Sebagian besar mereka sangat idealis dan sangat ingin mengabdi kepada agama dan masyarakat, meski mereka kecewa melihat bahwa kebanyakan tokohtokoh dan figur senantiasa siap berkompromi dalam menghadapi masalah politik dan sosial. Dalam pada ini para ulama tidak memberi penjelasan yang memuaskan tentang sebab-sebab semua penyakit sosial tadi, apalagi memberikan jalan keluar yang konkrit dan jelas. Ketidakpuasan inilah yang kemudian menjerumuskan mereka untuk mencari ajaran atau aliran baru yang dipandang memuaskan.

Ketiga, Terdapat jurang komunikasi antara tokoh-tokoh agama (baca: ulama dan kalangan cendekiawan Muslim) dan kalangan muda yang frustrasi tetapi idealis, sehingga kalangan yang disebut terakhir cenderung terhambat untuk menyalurkan aspirasi idealisme mereka ke dalam saluran yang lebih moderat dan produktif. Mereka kemudian menjadi radikal karena masih dangkalnya pengetahuan agama.Tidak mengherankan kalau kritik dan serangan kelompok sempalan terhadap ulama "ortodoks" terkadang lebih keras daripada terhadap koruptor dan penguasa zalim sekalipun. ${ }^{6}$

Keempat, Sebagai akibat urbanisasi dan monetarisasi ekonomi, banyak ikatan sosial yang tradisional semakin longgar atau terputus. Dalam desa tradisional, setiap orang adalah anggota sebuah komunitas yang cukup intim, dengan kontrol sosial yang ketat tetapi juga dengan sistem perlindungan dan jaminan sosial. Jaringan keluarga yang luas melibatkan setiap individu dalam sebuah 
sistem hak dan kewajiban yang sampai batas tertentu menjamin kesejahteraannya. Dalam masyarakat kota modern, sebaliknya, setiap orang berhubungan dengan jauh lebih banyak orang lain, tetapi hubungan ini sangat dangkal dan tidak mengandung tanggungjawab yang berarti. Komunitas, seperti di desa atau di keluarga besar, sudah tidak ada lagi, dan kehidupan telah menjadi lebih individualis.Itu berarti bahwa dari satu segi setiap orang lebih bebas; tetapi dari segi lain, tidak ada lagi perlindungan yang betul-betul memberikan jaminan. Dalam keadaan seperti ini banyak orang merasa terisolir, dan merasa bahwa tak ada orang yang betul-betul bisa mereka percayai karena sistem kontrol sosial dengan segala sanksinya sudah tidak ada lagi, dan karena orang lain juga lebih mengutamakan kepentingan individual masing-masing. ${ }^{7}$

Akibatnya dalam situasi seperti ini aliran agama sering dipandang bisa memenuhi kekosongan yang telah terjadi karena menghilangnya komunitas keluarga besar dan desa.Namun untuk dapat berfungsi sebagai komunitas, aliran ini mestinya cukup kecil jumlah anggotanya, sehingga mereka bisa saling mengenal. Aspek komunitas dan solidaritas antara sesama anggota diperkuat lagi kalau aliran ini membedakan diri dengan tajam dari dunia sekitarnya.

Dari beberapa alasan yang menyeret lahirnya gerakan sempalan di atas, agaknya daya tarik aliran yang bersifat eksklusif (yaitu menghindar dari hubungan dengan umat lainnya) menjadi penyebab utama yang memicu tumbuh suburnya gerakan sempalan di kalangan umat Islam di Indonesia. Eksklusifitas ini kemudian diperparah dengan minimnya pengetahuan dan dasar-dasar keagamaan, sehingga mereka mudah terjebak dan terpedaya oleh aliran sesat atau gerakan sempalan tersebut.

Adanya tulisan ini berangkat dari kegelisahan penulis terkait munculnya gerakan sempalan yang banyak menimbulkan reaksi dan respon dari masyarakat baik secara individu, ataupun kelompok organisasi bahkan yang menjadi riskan adalah sampai terjadi bentrok fisik diberbagai daerah di tanah air.Pemahaman masyarakat Indonesia pada umumnya gerakan sempalan dalam Islam ditujukan pada gerakan aliran Ahmadiyah dan Syiah. Sintesa ini berangkat dari urgensi banyaknya konflikkonflik yang terjadi diberbagai wilayah di Indonesia terindikasi karena menganggap bahwa Aliran Ahmadiyah dan Syiah telah menyimpang dari ajaran Islam pada umumnya. Sebut saja konflik Sunni-Syiah di Sampang, Madura. Pengrusakan tempat ibadah Ahmadiyah di Kuningan dan di Parung Bogor adalah peristiwaperistiwa yang bisa diambil contoh untuk sekian banyak peristiwa yang ada di wilayah Indonesia. Meskipun kasus serupa tidak terjadi di wilayah-wilayah yang lain. Oleh karena itu jurnal ini akan lebih menyoroti bagaimana perkembangan Aliran Ahmadiyah dan Syiah pada umumnya, dengan harapan agar bisa mengambil ibroh dan pelajaran dalam bersikap secara bijak dan mampu mendialogkan keberagaman kehidupan bergama di Indonesia.

\section{Ahmadiyah}

Jemaat Ahmadiyah merupakan gerakan atau organisasi Islam 
internasional yang didirikan oleh Mirza Ghulam Ahmad di kota Ludhiana India pada 1889. Ia dilahirkan pada 13 Febuari 1835 di Qadian, India, dan meninggal dunia di kota Lahore India pada 26 mei 1908. Pada akhir 1890, Ghulam Ahmad menyatakan diri sebagai Imam Mahdi dan Al-Masih, Al-Mahdi (Imam Mahdi) adalah wahyu yang ia akui dan terima dari tuhan, juga sebagai nabi (bagi aliran Qadian) dan mujadid (bagi aliran lahore) merupakan ideology inti bagi Ahmadiyah sesudah Ghulam Ahmad wafat pada 1908, pemimpin jemaat Ahmadiyyah diteruskan oelh para imam jemaat Ahmadiyah yang disebut Khalifatul masih. Khalifatul MAsih I adalah Hakim Nuruddin yang wafat pada 1914, khalifatul Masih II adalah Mirza Bashirudin Mahmud Ahmad yang wafat pada 1965, Khalifatul Masih III adalah Mirza Natsir Ahmad M.A yang wafat pada 1982, Khalifatul Masih IV adalah Mirza Tahir Ahmad yang wafat pada 2003 dan khalifatul masih $\mathrm{V}$ adalah mirza Masroor Ahmad yang sekarang memimpin Jemaat Ahmadiyah di seluruh dunia dan markas pusat saat ini berada di London, Inggris.

Penyebaran paham Ahmadiyah dibandung dilakukan setelah mubaligh Ahmadiyah, M. Abdul Wahid pindah dari Garut ke Bandung pada 1938. Ia tinggal di daerah nyengseret dengan menyewa sebuah rumah sederhana berbentuk panggung dari bamboo, namun demikian, sebenarnya dibandung pada 1934 telah ada seorang anggota jemaat Ahmadiyah bernama Abdul samik yang pernah belajar paham Ahmadiyah di Qadian, India seorang tabib pakar telinga dan pedagang yang berasal dari padang. Dalam usahanya membuat obat herbal, ia dibantu oleh empat orang kawannya, yaitu nazir, ata, saud, dan Basyir yang berasal dari minagkabau. Untuk penyebaran paham ahmadiyah, beliau bertabligh kepada kawan-kawannya itu, namun hanya dua orang yang tertarik dengan paham Ahmadiyah itu yaitu Basyir dan Nazir.

M. Abdul Wahid berusaha untuk menghimpun para anggota jemaat Ahmadiyah yang ada di bandung dengan tujuan untuk memperkuat keluarga jemaat Ahmadiyah yang nantinya akan menyebarkan paham Ahmadiyah. Usahan pertamanya ia lakukan dengan membimbing para anggota jemaat dengan mengadakan sembahyang jemaat dirumahnya yang diikuti oleh tujuh orang saja, yaitu M. Abdul Wahid dan Isterinya, Abdul Samik dan isterinya , H. Marah Wahab dan Isterinya, dan M. Malik Azis Ahmad Khan.

Untuk lebih meningkatkan lagi penyebaran Ahmadiyah, M. Abdul Wahid sekeluarga pindah ke jalan pejagalan No. $35 \mathrm{C}$, berdekatan dengan rumah Abdul Samik, Seorang Ahmadi yang pertama di Bandung. Setelah berada ditempat itulah mereka mendirikan Ahmadiyah Cabang Bandung dengan pengurusnya, yaitu Ajusar Gelar Sutan Palindih (ketua), A. Jubari (Sekretaris), Moch. Hambali (Keuangan), Abdul Samik (Ummur amah) dan R.Usman Sabandi (Sekretaris tabligh).

Berbagai aktivitas Ahmadiyah di Bandung dilakukan dengan baik hingga masuknya tentara jepang pada tahun 1942. Pada masa awal peerintahan pendudukan tentara jepang semua organisasi secara resmi di bubarkan, termasuk Ahmadiyah. Namun demikian, sembahyang jumaat. Pada masa itu, anggota jemaat Ahmadiyah Bandung tidak bertambah 
karena tidak ada aktivitas pertablighan yang berarti. Pertablighan jemaat Ahmadiyah di Bandung tidak dapat berjalan dengan baik pada revolusi kemerdekaan Indonesia karena pada umumnya rakyat Indonesia berjuang untuk mempertahankan kemerdekaannya. Semua anggota jemaat Ahmadiyah pun turut berjuang membela Negara sesuai dengan kemampuannya. M. Abdul Wahid bekerja di Radio Republik Indonesia (RRI) Bandung pada bagian bahasa Urdu dibantu oleh seorang utusan dari Qadian M. Malik Azis Ahmad Khan untuk memberikan informasi kepada masyarakat internasional tentang kemerdekaan Indonesia. Pekerjaan itu ia lakukan sampai terjadi pertiwa "Bandung Lautan Api" pada 24 Maret 1946. Oleh karena itu keadaan pada masa itu sangat tidak menentu maka banyak penduduk kota Bandung, termasuk para anggota jemaat Ahmadiyah mengungsi ke daerahdaerah diluar Bandung, seperti ke Majalaya, Garut, Sumedang, Tasikmalaya, dan Ciamis. Pada masa itu M. Abdul Wahid mengungsi ke kota Garut.

Setelah keadaan di Bandung agak aman, banyak orang yang mengungsi itu kembali lagi ke Bandung. M. Abdul Wahid kembali lagi ke bandung beserta beberapa anggota jemaat Ahmadiyah dan menyewa sebuah rumah di gang maksudi, Bojongloa. Untuk menghidupkan lagi aktivitas jemaat Ahmadiyah, para anggota jemaat Ahmadiyah, para anggota jemaat Ahmadiyah membangun masjid di gang H. Sapari. Tanah untuk pembangunan sebesar Rp. 1.200. masjid yang dibangun pada 1948 itu selesai dibangun pada 1950 dengan biaya dari kaum ibu di garut dan Bandung . selama masa 1950-an, Abdul
Wahid dengan dibantu oleh para anggota jemaat lainnya tetap melakukan bimbingan kepada para anggotanya, diantaranya perjanjian al-Qur'an, pemungutan candah, dan mengadakan pertemuan untuk kepentingan jemaat Ahmadiyah. Setelah merasa mantap maka penyebaran Ahmadiyah di luar Bandung barudilakukan lagi dengan baik pada awal 1960-an, yaitu dengan didirikannya paham Ahmadiyah Cimahi pada 1960, di Rajamandala dan Majalaya pada 1963, di Banjaran pada 1979, di Soreang pada 1998, dan Arjasari 1999.

\section{Syiah}

Ada yang menduga Syiah datang pada abad ke-12 Masehi, ada yang percaya bahwa orang-orang Syiah sudah datang ke Kepulauan Nusantara jauh sebelum abad ke-12 itu. Ada yang meyakini ajaran Syiah dibawa oleh orangorang Persia, namun ada juga yang meyakini Syiah diperkenalkan oleh orangorang Arab langsung. Para pemeluk Syiah di Indonesia sekarang banyak yang percaya, para pembawa Islam ke Indonesia ini adalah orang-orang Syiah. Bukan para sufi. Bukan pula para pedagang yang bermazhab Syafi'i. Namun, karena melakukan taqiyyah, orang-orang Syiah pertama yang dimaksud berpura-pura menjalankan praktek-praktek Islam berdasarkan mazhab Syafi'i sampai akhirnya mazhab Syafi'ilah yang dikenal dan dicatat sejarah sebagai mazhab tertua yang berkembang di Indonesia. 8

Lebih jauh lagi, dalam atlas walisongo Agus Sunyoto menjelaskan, penguasa muslim pertama di Nusantara yang bernama Sultan Malik Ash-Shalih adalah penguasa Samudera Pasai pertama 
yang memeluk Syiah. Seperti yang dicatat sejarah, Kesultanan Samudera Pasai dikenal sebagai kesultanan tertua di Nusantara yang bermazhab Syafi'i. Keyakinan itu, ternyata, didasarkan pada catatan perjananan Ibnu Batutah, seorang pelancong dari Maroko, yang pernah singgah di Aceh pada tahun 1345-1346 M. Ia menulis,

"Sultan Jawa bernama Sultan Malik Azh-Zhahir. Ia adalah sosok yang disegani dan dihormati. Lebih dari itu, ia termasuk penganut Mazhab Syafi'i. Ia juga sangat mencintai para fuqaha' yang datang ke majelisnya untuk bertukar pendapat. Masyarakat mengenalnya sebagai sosok yang senang berjihad dan berperang, namun juga rendah hati. Ia datang ke masjid untuk menunaikan shalat Jum'at dengan berjalan kaki. Para penduduk Jawa mayoritas bermazhab Syafi'iyyah. Mereka senang berjihad bersama sultan, hingga mereka memenangkan peperangan melawan orang-orang kafir. Bahkan, orang-orang kafir membayar jizyah kepada sultan sebagai bentuk perdamaian. ${ }^{9}$

Apakah Ibnu Batutah dapat dipercaya? Sepertinya, kita semua sudah tahu jawabannya. Amat disayangkan, klaim orang-orang Syiah itu diperkuat oleh pendapat dari kalangan para pemerhati sejarah Islam di Indonesia. S.Q. Fatimi, A. Hasjmy, Wan Husein Azmi, Abu Bakar Aceh, dan Agus Sunyoto adalah orang-orang yang pernah menulis bahwa Syiah telah ada pada masa-masa pertama perkembangan Islam di Kepulauan Nusantara.
Orang-orang Syiah tersebut lebih memilih mendakwahkan Syiah kepada orang-orang terdekat mereka, seperti kepada anggota keluarga sendiri. Lagi pula, yang terpenting bagi waktu itu adalah bagaimana mereka tetap eksis sebagai seorang Syiah, meski dalam hati atau meski di tengah keluarga.

Jelas saja, karena laku taqiyyah khas Syiah itu, mengira-ngira sedikit atau banyak orang yang memeluk Syiah pada gelombang pertama ini menjadi sebuah kemustahilan. Kendati demikian, salah seorang ulama Syiah asal Lebanon, Muhammad Jawad Mughniyyah, pernah menyebutkan dalam bukunya yang terbit pada 1973, bahwa para pemeluk Syiah di Indonesia pada waktu itu berjumlah satu juta orang.

Yang juga patut dicatat, sebelum Revolusi Iran meletus pada 1979, sejumlah pemuda Indonesia sudah ada yang berangkat dan belajar di Qum, Iran. Selain Najaf dan Karbala di Irak serta Masyhad di Iran, Qum menjadi salah satu dari empat kota suci milik Syiah yang banyak dikunjungi untuk keperluan ziarah dan belajar.

Di Qum, para pemuda yang dimaksud memperdalam ajaran Syiah di hawzah-hawzah ilmiyah, semacam lembaga pendidikan tradisional di kalangan Syiah yang dalam bahasa Indonesia dapat dimaknakan sebagai pondok pesantren atau juga madrasah. Mereka belajar di situ atas tanggungan ulama-ulama Syiah setempat yang mendapat biaya untuk itu lewat uang zakat dan khumus. ${ }^{10}$

Dalam upaya-upaya merakit persatuan umat, adalah dua hal yang dilakukan oleh orang-orang Syiah di Indonesia. Membuat Buku Putih Mazhab 
Syiah, yang memuat uraian-uraian untuk kesefahaman demi kerukunan umat Islam. Tidak akan ada persatuan dan kerukunan, kalau tidak ada kesefahaman. Lalu, tidak bisa pula ada kesefahaman kalau tidak ada upaya yang sungguh-sungguh untuk memfahami diri masing-masing. Setiap diri atau ke-lompok harus memfahami dirinya sendiri dan kemu-dian memfahami pihak lain. Buku Putih Mazhab Syiah merupakan upaya memperkenalkan Syiah agar difahami dengan benar. Hal ini tidak cukup jika pihak di luar Syiah tidak memfahami dirinya. Kesefahaman, dengan demikian, sangat perlu sebab kesalahfahaman. hanyalah akan menyimpan potensi konflik. Boleh jadi, berbagai konflik seperti yang terjadi dalam masyarakat Islam di dunia dan di Indonesia ini merupakan akibat dari kesalahfahaman. Ringkasnya, jika disederhanakan, mungkin ada kesalahfahaman orang Syiah terhadap Mazhab Syiah, dan kesalahfahaman orang Sunni terhadap Mazhab Sunni.

Untuk memperjelas persoalan tersebut. Pertama, persoalan penting dan mendesaknya kesalingfahaman serta upaya mengatasi kesalahfahaman. Tidak dimungkiri oleh siapa pun bahwa Syiah, atau yang dinamai Syiah, banyak kelompoknya. Itu sebabnya, kalau ada pendapat dari satu kelompok Syiah yang dinisbatkan kepada kelompok lain, maka di sini bisa timbul kesalahfahaman. Suatu contoh, ada Syiah Ismailiyah, ada Syiah Zaidiyah, yang sekarang banyak dan berkembang di Yaman. Ada juga Syiah Ja'fariyah yang juga sekarang masih berkembang utamanya di Iran dan Irak. Hingga sekarang ini masih terdapat perbedaan di antara pemahaman Syiah tersebut. Dulu ada Syiah Al-Khathaniyah, Al-Qaramithah, dan puluhan lagi aliran Syiah lainnya. Jika pendapat salah satu alir-an Syiah, misalnya Khathaniyah lalu dinisbatkan ke Ja'fariyah, maka akan terjadi kesalahfahaman, dan itu merupakan bentuk penzaliman atas salah satu kelompok itu.

Kita tidak bisa memungkiri bahwa ada Syiah yang sesat. Bahkan tidak dapat dimungkiri bahwa ada ke-lompok Syiah yang menyesatkan kelompok Syiah yang lain. Salah satu keluhan kita terhadap kecaman-ke-caman atas Syiah adalah adanya kebiasaan mengutip pendapat suatu kelompok dan menganggapnya bahwa itu sama dengan pendapat kelompok lain dan atas dasar itulah kelompok lain disesatkan. Ini bentuk ketidakfahaman.

Penulis melihat di sisi Sunnah pun begitu. Semua sepakat bahwa perilaku gampang mengkafirkan adalah perilaku yang tidak terpuji. Dan "jangan mengkafir-kan" adalah ajaran Sunnah. Imam Ghazali misalnya berkata: "kalau seandainya Anda mendengar kalimat mengkafirkan suatu kelompok yang diucapkan oleh seseorang, yang 99 persen di antaranya menunjukkan bahwa yang bersangkutan benar-benar kafir, ketahuilah masih ada satu persen yang memungkinkannya dini-lai beriman, maka jangan kafirkan dia." Membiarkan hidup seribu orang yang kafir, kesalahannya lebih ri-ngan daripada membunuh karier seorang Muslim. Namun sayangnya, ini tidak diketahui oleh banyak orang.

Ketidaktahuan atau ketidakmengertian satu pihak atas dirinya dan pihak lain, mengakibatkan terjadinya 
cekcok. Kedua, menuju kebersatuan umat Islam. Fakta sejarah manusia menunjukkan adanya berbagai per-kembangan pemikiran. Pemikiran apa pun, termasuk keagamaan, dipengaruhi oleh banyak faktor. Berma-cam-macam faktor itu bisa berupa perkembangan ilmu, kemaslahatan, kecenderungan seseorang, dan sebagainya. Pada semua mazhab pasti terjadi perubah-an-perubahan menyangkut pendapat-pendapat mazhabnya, sedikit ataupun banyak. Pendapat Imam Syafi'i, jangankan oleh orang lain, oleh perkembangan di-rinya sendiri pun tatkala di Irak dan di Mesir, meng-alami perkembangan. Artinya, pendapat beliau ketika masih di Irak sudah berubah atau berkembang diban-ding saat beliau sudah berada di Mesir. Begitu pun ter-jadi pada faham salaf. Banyak Salafiyah sekarang ini yang sudah berbeda pandangannya dengan pendapat Imam Ahmad ibn Hanbal. Sekali lagi, ada per-kembangan.

Kemaslahatan umat telah menjadi topik penting saat ini. Topik yang menggugah banyak tokoh Muslim untuk berpikir tentang pentingnya upaya baru dalam mendekatkan umat Islam dari berbagai latar mazhab. Kemaslahatan umat Islam telah mengantar sebagian tokoh-tokohnya untuk melakukan pendekatan-pende-katan pemikiran dan pertimbangan-pertimbangan ba-ru. Kalau tidak demikian, maka dapat disamakan de ngan orang yang terlambat lahir. Buku saya yang ber-judul Sunnah-Syiah Bergandengan Tangan: Mung-kinkah! telah dibantah oleh suatu pesantren. Jika saya bereaksi dengan membantahnya lagi, saya merasa terlambat lahir. Bantahan yang dikemukakan itu ma-sih merujuk kepada pendapat-pendapat lama yang sudah tak relevan lagi. Topik-topiknya tidak lagi kon-tekstual dengan kebutuhan umat saat ini.

Mungkin akan lain halnya jika sumber-sumber rujukannya ialah ulamaulama yang sudah akrab dengan proses kontekstualisasi pemikiran keislaman dalam konteks tantangan baru dan perkembangan zaman. Beberapa ulama Syiah memberi penjelasan bahwasa-nya juga telah terjadi perkembangan pendapat-penda-pat para ulama tentang ajaran mazhab ini. Salah satu contohnya adalah tulisan Imam Khomeini menyangkut taqiyyah. Pendapatnya sudah sangat berbeda. Demi-kian juga pendapat tentang izin mengangkat senjata terhadap penguasa. Dahulu, tidak ada izin itu hingga hadirnya imam (Mahdi, yang dipercayai sedang gaib), tetapi sekarang sudah ada perkembangan. Hal-hal ini menunjukkan bahwa jika pendapat suatu mazhab hanya merujuk pada sumbersumber lama tanpa mem-pertimbangkan perkembangannya yang lebih muta-khir, maka muncullah salah faham. Ketiga, pendapat ulama, cendekiawan, berbeda dengan pendapat orang awam. Syaikh Abdul Halim Mahmud dalam bukunya At-Tafkir AlFalsafi fi Al-Is-lam mengatakan: "Kita tidak bisa menilai orang-orang Prancis dan pemikiran-pemikirannya dengan memperhatikan orang-orang di desa-desa Prancis yang bodoh." Demikian juga beliau nyatakan bahwa orang Mesir tidak bisa digambarkan hanya dengan pemikiran orang-orang Mesir yang masih telanjang kaki, pa-dahal ada cendekiawannya yang begitu hebat pemikir-an-pemikirannya.

Sering suatu kelompok dinilai tidak dari ulamanya, baik Sunni menilai Syiah 
maupun Syiah menilai Sunni. Tidak mungkin ada kesefahaman jika demikian hal-nya. Rujukan terbaik adalah ulama yang muktabar dan diakui, bukan seseorang atau kelompok apa pun namanya, apalagi yang sebenarnya tidak diakui seba-gai ulama. Bukan hanya di kalangan Syiah, di kalangan Sunni pun banyak. Sebagai contoh, yang saya pelajari di Sunni, tentang pendapat para ulama hadis menyang-kut kualifikasi Imam Ghazali dalam bidang hadis. Me-nurut pendapat Imam Jalaluddin Suyuti, seperti di-kutip Syaikh Muhammad Rasyid Ridha, "(Kualifikasi Al-Ghazali) itu laksana pengumpul kayu di malam hari." Artinya, Imam Ghazali dianggap mencampur baurkan hadis-hadis sahih dan lemah. Hal seperti ini bisa terjadi, apalagi pada zaman seperti sekarang ini.

Seorang penulis besar di Mesir, almarhum Abdul Qadir Audah menyatakan tentang problem umat Islam dengan ungkapan "Al-Islam baina Jahli Abnaihi wa 'Ajzi Ulama'ihi", Islam berada di antara kebodohan umatnya dan ketidakmampuan ulamanya. Ketika ada sebagian anggapan orang bahwa Pak Quraish itu Syiah, saya tegas membantahnya. Penolakan saya disebut Syiah bukan karena ikut pendapat bahwa Syiah itu sesat, tetapi karena saya tahu siapa yang dimaksud Syiah, saya sangat memfahami siapa yang pantas di-sebut Syiah.

Syaikh Abdul Halim Mahmud, guru saya, dan saya akrab dengan beliau, berkata: "Jangan beranggapan bahwa seorang yang berpendapat bahwa Sayyidina Ali ibn Abu Thalib lebih utama daripada Sayyidina Abu Bakar atau Utsman itu Syiah." Karena, seperti ditulis
Syaikh Abdul Halim Mahmud, sejarah menunjukkan ada kelompok Mu'tazilah Bashrah yang bahkan me-musuhi Syiah, tetapi menganggap Sayyidina Ali lebih afdhal daripada Sayyidina Abu Bakar, Umar, dan Uts-man. Dan ini beda dengan Mu'tazilah di Baghdad.

Pernah terjadi dialog ulama dari berbagai mazhab. Imam Abu Hanifah berkata, "Yang tidak shalat, kafir." Lalu Imam Syafi'i berkata, “Tidak, dia tidak kafir," lalubertanya, "Bagaimana caranya orang yang tidak shalat yang Anda katakan sebagai kafir tersebut agar dapat masuk Islam kembali?" Jawab Imam Abu Hanifah, "Dia ucapkan dua kalimat syahadat." Lalu, Imam Syafi'i menyanggahnya dengan mengatakan bahwa dia ti-dak pernah meninggalkan dua kalimat syahadat. Se-hingga menjadi aneh kalau mengucapkan dua kalimat syahadat harus menjadi syarat agar dirinya dapat kembali menjadi Islam. "Jadi, dia tidak kafir, dia ada-lah Muslim yang berdosa," lanjut Imam Syafi'i.

Semua yang mengaku Muslim merujuk ke Al-Quran, bahkan tidak jarang orang non-Muslim pun bersikap demikian tatkala menghadapi umat Islam. Semua Muslim merujuk kepada Al-Quran, namun jus-tru salah satu penyebab perbedaan di antara umat Is-lam adalah Al-Quran. Artinya, yang menjadi perbedaan adalah Al-Quran. Imam Syafi'i merujuk kepada Al-Quran, demikian juga dengan Imam Abu Hanifah, Imam Ja'far, dan Imam Zaid. Perbedaan terjadi karena hanya sedikit kesimpulan-kesimpulan yang benar-be-nar diambil dari Al-Quran dan Sunnah.

Perbedaan terjadi tatkala sudah memasuki wilayah penafsiran. Tangan 
yang dimaksud dalam kalimat"Yadullâhi fawqa aidîhim" itu hakiki atau majazi? Ada tangan Tuhan, tapi beda dengan makhluk. Ini metafora. Ini menyebabkan perbedaan. Kata "masaha" se cara bahasa, apa artinya? Ini menimbulkan juga perbedaan dalam fiqih wudhu. Apakah berarti meng-usap (masaha), atau bertinggi (saha), ini sudah beda juga. Ada juga persoalan i'rab. "Wamsahû bi ru'ûsikum wa arjulikum", atau arjulâkum? Keduanya merujuk kepada AlQuran. Yang satu berarti kaki diusap, yang satu lagi dibasuh.

Dapat tidaknya seorang musafir berpuasa juga menimbulkan perbedaan. Syiah menyatakan tidak bo-leh, Sunni membolehkan. Keduanya merujuk AlQuran dan Sunnah. "Fa man kâna minkum marîdhan aw 'alâ safarin fa'iddatun min ayyâmin ukhar." Sun-ni, karena mengikuti hadis, memfahaminya sebagai

"Man kâna minkum marîdhan aw 'alâ safarin (walam yashum)." Semua merujuk pada kemungkinan-ke-mungkinan yang berbeda-beda, yang masing-masing-nya tidak dapat dimutlakkan.

Hadis juga demikian. Ada perawi Bukhari yang dianggap tidak cukup kuat oleh Imam Muslim. Demi-kian pula di Syiah, Kitab Hadis Al-Kâfi tidak dianggap semua mutlak sahih. Sebagaimana di Sunni. Jangan-kan yang diriwayatkan oleh Imam Ahmad, dalam Shahîh Muslim pun ada yang tidak sahih menurut sementara ulama Sunni.

Hal terpenting dalam upaya menuju kesefahaman ini adalah kebersatuan dalam akidah. Ini pun rumus-annya tidak harus seragam atau sama persis. Yang terpenting adalah kesamaan kandungan dan substansi-nya. Syaikh Muhammad Abduh berkata bahwa Rukun Iman itu yang terpenting ada dua, yakni percaya kepada Allah dan Hari Kemudian. Perinciannya, menurut beliau, bahwa uraian tentang Hari Kemudian tak dapat diterima oleh akal kecuali melalui utusan Allah (Rasul), sehingga kita pun perlu beriman kepada Ra-sul. Rasul tak mungkin mengungkapkan itu melalui nalarnya sendiri, melainkan menerimanya dari malaikat. Maka iman kepada malaikat adalah hal yang sa-ngat penting. Jadilah rumusan Rukun Iman berkembang dari situ.

Umat ini seyogianya tidak terikat dengan rumusan, tetapi kandungan yang dirumuskan itu. Ini baru dapat menciptakan pintu ke arah kesefahaman dengan baik. Lain halnya jika yang dipaksakan adalah sefaham atas redaksi rumusan secara persis, dan itu tidak mungkin. Andaikata kesefahaman itu sudah dan terjadi, maka segalanya akan menjadi mudah. Apalagi kalau yang dirujuk adalah pendapat ulama tepercaya yang ada sekarang, baik Syiah maupun Sunni. Hal ini tentu akan menambah kuat prospek terwujudnya ke-sefahaman umat Islam, dan selanjutnya kerukunan yang dikehendaki bersama, sesuai perintah Allah Swt. Itu sebabnya semua konferensi atau pertemuan pertemuan yang diadakan oleh berbagai ulama, telah menghasilkan kesepakatan-kesepakatan.

\section{Kesimpulan}

Kehadiran gerakan sempalan dapat dilihat sebagai kritik terhadap ortodoksi yang telah ada. Selama dialog antara ortodoksi dan gerakan sempalan masih bisa berlangsung, fenomena ini mempunyai fungsi positif. Terputusnya komunikasi dan semakin terasingnya 
gerakan sempalan tadi justru mengandung bahaya yang lebih besar. Maka, apabila ortodoksi tidak responsif dan komunikatif lagi dan hanya bereaksi dengan melarang-larang (atau dengan diam saja), ortodoksi sendiri merupakan salah satu sebab penyimpangan "ekstrim" ini.

Menyikapi keberadaan kelompokkelompok sempalan di atas haruslah arif, objektif dan proporsional.Seyogyanya keberadaan kelompok-kelompok atau aliran-aliran tersebut diserahkan sepenuhnya kepada mekanisme pasar dan penilaian masyarakat.Hal ini disebabkan karena suatu keyakinan adalah idea yang bersedia untuk bertindak, dan agama bagi manusia bersifat fungsional dan dinamis.Dalam konteks ini, agama, aliran ataupun keyakinan tertentu adalah diperlukan apabila berguna bagi kehidupan, artinya dapat memberi pengaruh bagi kehidupan manusia. Satu hal yang harus di ingat bahwa bangsa Indonesia tidak takut dari ancamanan teror apapun, masing-masing dari warga negara Indonesia apapun agama dan sukunya akan selalu menjunjung tinggi semangat kesatuan dalam keragaman berbangsa dan bernegara.

\section{Endnote}

\section{${ }^{1}$ Kristianto \& Zen, 2009, hal. 11 \\ ${ }^{2}$ Nawawi, 1997, hal. 63. \\ ${ }^{3}$ Attabik Ali \&A Zuhdi Mudlor,} 1678.

${ }^{4}$ Sebagian memasukan Imam Ja'far ashShidiq sebagai Mujtahid Mutlak sehingga madzhab fiqh menjadi lima.

${ }^{5}$ Nunu Burhanudin, 2010: 1.

${ }^{6}$ Martin Van Bruinessen, 1992: 27.

${ }^{7}$ (Martin van Bruinessen, 1988: 55.

${ }^{8}$ Rimbun Natamarga, Majalah AsySyari'ah Vol. VIII, No. 92, 1434H/2013M.

${ }^{9}$ Agus Sunyoto 2009: 77."
${ }^{10}$ Dalam fikih Syiah Imamiyah/Itsna 'Asyariyah, zakat mal dibedakan dari apa yang mereka istilahkan dengan khumus. Khumus adalah pungutan di luar zakat mal dalam bentuk (a) harta rampasan perang, (b) barang tambang seperti emas, perak, besi, kuningan, batu-batuan berharga, belerang, minyak bumi berikut segala jenisnya ketika telah mencapai nishabnya yang senilai 20 dinar atau 200 dirham, (c) harta karun yang ditemukan di dalam tanah serta tidak diketahui siapa pemiliknya dan telah mencapai jumlah senilai 20 dinar atau 200 dirham, (d) segala sesuatu yang didapatkan dari dalam laut dengan menyelam berupa barang-barang berharga seperti mutiara dan memiliki nilai 1 dinar atau lebih, (e) tanah yang dibeli oleh seorang kafir dzimmi dari seorang muslim, (f) harta campuran antara yang halal dan yang haram tetapi tidak diketahui pasti jumlah yang haramnya dan siapa pemiliknya, (g) kelebihan penghasilan apa saja dalam satu tahun dari kebutuhan hidup di tahun itu di luar harta yang berupa hadiah, mas kawin, sedekah, jatah khumus, dan warisan. Bagi orang-orang Syiah, khumus dikhusukan untuk Allah, Rasulullah, dzawil qurba, anak-anak yatim, orang-orang miskin, dan ibnu sabil. Namun, pada masa menghilangnya imam kedua belas Syiah Imamiyah, bagian yang khusus untuk Allah, Rasulullah dan dzawil qurba diserahkan kepada ulama-ulama Syiah yang menjadi rujukan (marja') orang-orang Syiah umumnya. Selain itu, bagian tersebut juga dapat diserahkan kepada wakil-wakil ulama-ulama yang dimaksud atau orang-orang yang telah mereka rekomendasikan. Dalam keyakinan Syiah Imamiyah, khumus itu tidak digunakan kecuali untuk hal-hal yang diridhoi, disetujui, oleh imam kedua belas mereka. Sementara itu, bagian khumus yang untuk anak-anak yatim, orang-orang miskin, dan ibnu sabil sebelum diserahkan kepada orang-orang yang berhak harus terlebih dahulu mendapatkan izin dari ulama-ulama Syiah yang jadi rujukan. Di Indonesia sekarang ini, sudah banyak berdiri lembaga-lembaga penyalur khumus dari para pemeluk Syiah. Di antara lembaga-lembaga penyalur khumus itu adalah Yayasan Dana Mustadhafin yang berdiri lewat Akte Notaris No. 24 Tahun 2008 (disahkan oleh Menteri 
Kehakiman dan HAM RI lewat Surat Keputusan AHU-1990 AH.01.02 Tahun 2008) dan telah terdaftar di Dinas Mental Spiritual dan Kesejahteraan Sosial Departemen Sosial Provinsi Jakarta dengan nomor 08.03.74.04.1005-1310 B.

\section{DAFTAR PUSTAKA}

I. Buku

Ali, Attabik \&A Zuhdi Mudlor. (tanpa tahun) Kamus Kontemporer Arab Indonesia. Yogyakarta: Multikarya Grafika.

Abubakar, I., \& Muchtadlirin (ed). (2001). Media dan Integrasi Sosial Jembatan antar Umat Abaza, Mona 2004 "Markets of Faith: Jakartan Da'wa and Islamic Gentrification" Archipel 67: 173-202

Abbas, Siradjuddin 1969 I'itiqad Ahlussunnah Wal-Jama'ah. Jakarta: Pustaka Tarbiyah

Abdillah, Masykuri 1997 Responses of Indonesian Muslim Intellectuals to the Concept of Democracy (1966-1993). Hamburg: Abera Verlag Meyer \& Co. Beragama. Jakarta: CSRC UIN Syarif Hidayatullah.

Abduh, Umar 2001 Pesantren alZaytun Sesat: Investasi Mega Proyek dalam Gerakan NII. Jakarta: Darul Falah

Eriyanto. (2001). Analisis wacana: Pengantar analisis teks media. Yogyakarta: PT. Lkis.

Eriyanto. (2003). Media dan konflik ambon. Jakarta: KBR68H.

Hall, S., Critcher, C., Jefferson, T., Clarke, J., \& Roberts, B. (1978). Policing the crisis. London: Macmillan.

Hamad, I. (2004). Konstruksi realitas politik dalam media massa. Jakarta : Granit.

Kamus Besar Bahasa Indonesia. 2012.
Kristianto, A.E., \& Zen, P.M (ed). (2009). Refleksi keberagaman agama: Hukum sesat dan menyesatkan hukum. Jakarta: YLBHI.

Moelong, L.J. (2001). Metode penelitian kualitatif. Bandung: Remaja Rosdakarya.

Muhammad Mustofa. 2002. Memahami Terorisme: Suatu Perspektif Kriminologi. Jakarta: Jurnal Kriminologi Indonesia FISIP UI Vol. 2 No. III. Hal: 30.

Moeflich Hasbullah. 2012. Sejarah Sosial Intelektual Islam di Indonesia. Bandung: Pustaka Setia. Hal: 191-192.

Nawawi, H. (1997). Metode penelitian bidang sosial. Yogyakarta: Gadjah Mada University Press.

Nimmo, D. (2005). Komunikasi politik: Khalayak dan efek. Bandung: PT Remaja Rosdakarya.

Nugroho, B., Eriyanto., \& Surdiasis, F. (1999). Politik media mengemas berita. Yogyakarta: Institut Studi Arus Informasi.

Sirait, H. (2007). Jurnalisme sadar konflik: meliput konflik dengan perspektif damai. Jakarta: Aliansi Jurnalis Independen.

Sobur, A. (2009). Analisis teks media: Suatu pengantar untuk analisis wacana, analisis semiotik, dan analisis framing. Jakarta: PT Remaja Rosdakarya.

Solahudin. 2011. NII Sampai JI: Salafy Jihadisme di Indonesia.

Yursak, F. (2007). Eddie Widiono: Di bawah pusaran media. Jakarta: Next Reign Media.

II. Jurnal dan Makalah

Burhanudin, Nunu. 2010.“Tipologi Gerakan Sempalan di Kalangan UmatIslam Indonesia: Analisis Sosiologi Dan 
Fungsional", Annual Conference on Islamic Studies X.

Majalah Sabili, Edisi 15 Tahun XVIII,

17 Maret 2011Sofianto, Kunto. 2013.

Gerakan Sempalan Islam di Jawa Barat. Makalah Seminar Nasional Fakultas Adab dan Humaniora UIN Sunan Gunung Djati.

Van Bruinessen, Martin.

1992."Gerakan sempalan di kalangan umat Islam Indonesia: latar belakang sosial-budaya" ("Sectarian movements in Indonesian Islam: Social and cultural background"),Ulumul Qur'an vol. III no. 1.

Van Bruinessen, Martin. 1988. "Duit, Jodoh, Dukun: Remarks on Cultural Change Among Poor Migrants to Bandung", Masyarakat Indonesia XV.

III.Website

Ali Rokhmad, Aliran Sesat dan Hegemoni Ortodoksi, http://www. Arokhm./mfp./html

Jonathan T. Chow, 2005, "Asean

Counterterrorism Cooperation since 9/11." Asian Survey, Vol. 45, No. 2 (Mar. Apr., 2005), pp. 302-321. Published by: University of California Press Stable. Diunduh dari URL: http://www.jstor.org/stable/4497099.

(Diakses 30 September 2015).

Semakin Jelas Tempo Bela Ahmadiyah. Kamis, 17 Februari 2011. Diakses tanggal 7 September 2012 pukul 20.07, dari situs elektronik hidayatullah.com, http://www.hidayatullah.com/read/154 04/17/02/2011/semakin-jelas-tempobela-ahmadiyah.html

Terrorism File. 2000. History of Terrorism.

http://www.terrorismfiles.org/encyclopa edia/history_of_terrorism.html. (Diakses pada 20 September 2015).

Vidia Hamenda. 2015. Menelusuri Sejarah Terorisme di Bumi Indonesia. http://www.kompasiana.com/vidiahame nda/menelusuri-sejarah-singkatterorisme-di-bumiindonesia_554856a3547b618a16252506. (Diakses pada 20 September 2015). 